\title{
PERBANDINGAN PEMBIAYAAN BERMASALAH ANTARA BANK SYARIAH DENGAN BANK KONVENSIONAL
}

\author{
Maya Indriastuti \\ Jurusan Akuntansi, Univeristas Islam Sultan Agung, Semarang \\ Email: maya@unissula.ac.id \\ Ririh Dian Pratiwi \\ Jurusan Akuntansi, Univeristas Dian Nuswantoro, Semarang \\ Email: ririh.dian.pratiwi@dsn.dinus.ac.id
}

\begin{abstract}
The financing growth of sharia bank for five years is very strategic because it has become the main source of income for sharia bank. However, this growth was not followed by the position of nonperforming financing ratio which is in the second quarter of 2015 reached until 4.6\%. This figure is fair above the conventional bank's non-performing loans (NPLS) at $2.46 \%$ in the same period. This study analyzed and empirically tested the difference between sharia bank NPF and conventional bank NPL. The population in this study are all active and registered banks in Bank Indonesia from 20122016. Sampling method based on purposive sampling, with samples used are banks engaged in conventional and sharia in one institution as many as 10 Banks. The test results indicate that there are differences in non-performing financing between sharia banks and conventional banks. Average non-performing financing at sharia banks amounted to $2.64 \%$ while the average non-performing loans at conventional banks was $1.29 \%$. This indicates that the non-performing financing of sharia banks is worse compared to the non-performing loans in conventional banks. Therefore, sharia banks are more cautious in the distribution of working capital financing.
\end{abstract}

Keywords: sharia banking; conventional banking; non performing financing (NPF); non performing loans (NPL)

\begin{abstract}
ABSTRAK
Pertumbuhan pembiayaan bank syariah selama lima tahun ini sangat strategis karena telah menjadi sumber pendapatan yang utama bagi bank syariah. Namun, pertumbuhan ini tidak diikuti oleh posisi rasio pembiayaan bermasalah yang pada kuartal II tahun 2015 mencapai 4,6\%. Angka tersebut jauh di atas kredit bermasalah (NPL) bank konvensional di level 2,46\% pada periode yang sama. Penelitian ini menganalisis dan menguji secara empiris perbedaan NPF bank syariah dengan NPL bank konvensional. Populasi di penelitian ini adalah seluruh bank yang aktif dan terdaftar di Bank Indonesia dari tahun 2012-2016. Metode pengambilan sampel berdasarkan purposive sampling, dengan sampel yang digunakan adalah bank yang bergerak di konvensional maupun syariah dalam satu institusi sebanyak 10 Bank. Hasil pengujian menunjukkan bahwa terdapat perbedaan pembiayaan bermasalah antara bank syariah dengan bank konvensional. Rata-rata pembiayaan bermasalah pada bank syariah sebesar 2,64\% sedangkan rata-rata pembiayaan bermasalah pada bank konvensional sebesar 1,29\%. Hal ini mengindikasikan bahwa pembiayaan bermasalah pada bank syariah lebih buruk dibandingkan dengan pembiayaan bermasalah pada bank konvensional. Oleh karena itu, bank syariah lebih berhati-hati dalam penyaluran pembiayaan modal kerja
\end{abstract}

Kata Kunci: perbankan syariah; perbankan konvensional; non performing financing (NPF); non performing loan (NPL) 


\section{PENDAHULUAN}

Islamic Financial Services Industry Stability Report 2016, menyebutkan perbankan syariah Indonesia saat ini menjadi salah satu kontributor perkembangan perbankan syariah global yang diestimasi memiliki total aset sebesar \$1,9 triliun di akhir tahun 2016 dengan kontribusi sebesar 2,5\% dari total aset keuangan syariah global. Sementara dalam laporan Asian Development Bank tahun 2016 disebutkan bahwa Indonesia turut berkontribusi sebesar $13,4 \%$ dari seluruh aset perbankan syariah di Asia yang mencapai sebesar $\$ 209,3$ miliar.

Selain kontribusi asset, terdapat kontribusi lain yang dilakukan oleh bank syariah yakni pembiayaan. Pembiayaan merupakan sumber utama pendapatan perbankan selain penadapatan lain seperti fee based income. Kualitas pembiayaan yang disalurkan ini bisa menjadi kategori pembiayaan kurang lancar, pembiayaan dalam perhatian khusus, dan pembiayaan macet. Pembiayaan yang mengalami kemacetan atau gagal bayar dalam dunia perbankan syariah disebut dengan istilah Non Performing Financing (NPF). NPF merupakan salah satu indikator kesehatan bank syariah. Semakin tinggi nilai NPF maka semakin buruk tingkat kesehatan bank syariah tersebut. Tahun 2016, kualitas pembiayaan yang disalurkan BUS dan UUS semakin membaik dengan ditunjukkan oleh rasio Non-Performing Financing (NPF) gross yang mengalami penurunan sebesar $0,19 \%$ menjadi $4,15 \%$ dari $4,34 \%$ di tahun 2015 , begitu juga untuk rasio NPF net yang mengalami penurunan dari $2,77 \%$ menjadi 2,06\% (Bank Indonesia, 2016b). Perbaikan NPF utamanya dikontribusikan oleh penurunan NPF BUS dari 4,84\% menjadi $4,41 \%$, karena meningkatnya pembiayaan yang disalurkan bank syariah dan restrukturisasi pembiayaan.

Pembiayaan bermasalah juga dialami oleh bank konvensional dengan istilah yang berbeda, yakni Non Performing Loan (NPL). Perhitungan rasio NPF dan NPL adalah sama yaitu perbandingan antara pembiayaan/kredit bermasalah dengan total keseluruhan pembiayaan/kredit yang disalurkan Bank
Syariah/Bank Konvensional. Rasio NPL juga memiliki pengaruh yang sama dengan rasio NPF, dalam hal perlunya pembentukan PPAP dan risiko menurunnya laba yang dibagikan kepada nasabah simpanan. Non Performing Loan (NPL) masih menjadi salah satu topik menarik dalam isu perbankan saat ini, utamanya setelah krisis sering menerpa dan semakin rentannya posisi perbankan dalam perekonomian konvensional yang menggelembung (bubbles economy) seperti sekarang.

Selain sebagai salah satu indikator kesehatan perbankan, NPL juga bisa memberikan beberapa kandungan informasi terkait perkembangan sektor riil. Dari aspek pengelolaan perbankan, NPL dapat memberikan gambaran seberapa jauh manajer menjalankan pola pengelolaan kredit yang prudent. Kredit macet juga dapat menjadi indikator kelesuan sektor riil sebagai respon kondisi perekonomian secara umum. Bahkan dalam banyak penelitian, mulai dari prediksi bank gagal hingga indikator krisis ekonomi, tingkat NPL tak luput dari pengamatan (Faiz, 2010).

Otoritas Jasa Keuangan (OJK) mencatat, rasio kredit bermasalah atau Non Performing Loan (NPL) gross bank konvensional per akhir Juli lalu sudah mencapai 3,18\%. Rasio ini meningkat dibandingkan bulan sebelumnya yang sebesar 3,05\%. Menurut laporan keuangan perbankan pada semester pertama 2016, sebanyak enam bank dari 10 bank umum beraset terbesar, mencatatkan kenaikan rasio NPL. Sedangkan empat bank yang mengalami penurunan NPL gross. Mereka adalah Bank Tabungan Negara (BTN) dari 4,7\% pada Juni 2015 menjadi 3,41\% pada Juni 2016, Bank CIMB Niaga dari 4,38\% menjadi 3,97\%, dan Bank Negara Indonesia (BNI) dari 2,98\% menjadi 2,95\%. Sedangkan rasio NPL Bank Rakyat Indonesia (BRI) turun dari 2,33\% menjadi 2,31\% (Otoritas Jasa Keuangan (OJK), 2016).

Otoritas Jasa Keuangan (OJK) mengakui kualitas aset perbankan konvensional masih mengalami pemburukan, hal itu tercermin dari rasio kredit bermasalah (NPL) yang masih meningkat menjadi level $3 \%$ dari $2,9 \%$ pada 
bulan sebelumnya. Kendati demikian, OJK menegaskan industri perbankan telah mengantisipasi kenaikan NPL dengan meningkatkan pencadangan. Peningkatan NPL pada semester pertama 2016 ini merupakan kelanjutan dari tahun sebelumnya dimana beberapa sektor terpukul akibat pelambatan pertumbuhan ekonomi dunia (Otoritas Jasa Keuangan (OJK), 2016). Pada Mei, (Bank Indonesia, 2016a) Statistik Perbankan Indonesia mencatat kualitas aset dari sisi pinjaman tidak lancar (NPL) berlanjut memburuk karena level NPL naik menjadi 3,11\% dari 2,93\% pada April 2016, sementara level dari kredit dalam perhatian khusus (special mention loans, kategori 2) turun menjadi $5,70 \%$ dari $6,17 \%$.

\section{Permasalahan}

Pekembangan bank syariah yang cukup signifikan ternyata tidak diikuti oleh perkembangan nasabah dan produk yang memadai sehingga mengakibatkan tingginya non performing financing. OJK (2016) mengatakan bahwa salah satu penyebab tingginya rasio NPF khususnya pada akad murabahah dikarenakan pembiayaan bank syariah sangat erat kaitannya dengan sektor riil. Hal tersebut berimbas terhadap kinerja pembiayaan perbankan syariah.

Misra dan Dhal (2010) menyatakan bahwa bank besar lebih cenderung memiliki tingkat kredit macet yang lebih tinggi karena kendala neraca, sedangkan bank kecil dapat menunjukkan efisiensi yang lebih manajerial daripada bank-bank besar dalam hal penyaringan dan pemantauan pinjaman maupun pasca pinjaman, yang akan mengarah pada tingkat kegagalan yang lebih rendah. Pernyataan ini senada dengan penelitian yang dilakukan oleh Iqbal (2012) menyatakan bahwa ukuran perusahaan, CAR, ROA, dan ROE berpengaruh positif signifikan terhadap resiko likuiditas. Akhtar, et al., (2011) menemukan bahwa ukuran perusahaan dan modal kerja berpengaruh positif tidak signifikan terhadap resiko likuiditas. Firmansyah (2014) menemukan bahwa rasio likuiditas bank dapat mempengaruhi pembiayaan bermasalah. Faiz (2010) yang menunjukkan bahwa inflasi berpengaruh terhadap NPL.

Berdasarkan uraian diatas, maka rumusan masalah dalam penelitian ini adalah terdapat perbedaan pembiayaan bermasalah antara bank syariah dengan bank konvensional.

\section{Tujuan Penelitian}

Penelitian ini bertujuan untuk menganalisis dan menguji secara empiris perbedaan pembiayaan bermasalah antara Bank Syariah dengan Bank Konvensional.

\section{TINJAUAN PUSTAKA PENGEMBANGAN HIPOTESIS}

DAN

Pembiayaan bermasalah ini tetap menjadi momok yang menakutkan bagi perbankan. Apalagi, pengalaman membuktikan bahwa salah satu penyebab krisis ekonomi adalah kinerja perbankan yang buruk. Tingginya NPF dan NPL, khususnya kredit macet, memberikan kontribusi besar pada buruknya kinerja perbankan pada saat itu (Khediri et al., 2015).

NPF dan NPL digunakan sebagai salah satu indikator sehat tidaknya sebuah Bank serta digunakan untuk memprediksi prospek kelangsungan hidup (sustainability) bank tersebut. Data OJK di atas memberikan potret bahwa perlambatan industri perbankan syariah mulai menunjukkan sinyalnya di tahun 2012 . Kondisi ini berlanjut hingga tahun 2016. Penurunan pembiayaan perbankan syariah tentu saja otomatis akan mempengaruhi perolehan laba dan pada akhirnya bagi hasil industri perbankan syariah pun tidak akan sanggup berkompetisi dengan bank konvensional.

Non performing loan (NPL) yang merupakan aktiva produktif dengan kualitas aktiva kurang lancar, diragukan dan macet. Besarnya rasio NPL atau dalam perbankan syariah digunakan istilah NPF (non performing financing) yang diperbolehkan oleh Bank Indonesia adalah maksimal 5\%. Jika melebihi 5\% maka penilaian tingkat kesehatan bank yang bersangkutan akan terpengaruh, yaitu akan mengurangi nilai skor yang diperolehnya.

Adanya NPL pada sisi aktiva bank dapat memengaruhi likuiditas, rentabilitas serta 
solvabilitas bank. Likuiditas bank dapat memburuk akibat dari terjadinya ketidakseimbangan antara cash inflow (dari penerimaan bunga/bagi hasil serta angsuran penerimaan kredit oleh debitur) dan cash outflow (untuk membayar bunga/bagi hasil dan pelunasan dana masyarakat yang jatuh tempo oleh bank sendiri). Rentabilitas bank dapat menurun karena dengan terjadinya kredit macet tersebut sebagian penghasilan bunga bank tidak efektif diterima oleh bank, sementara bank masih tetap harus membayar bunga atas penempatan dana masyarakat pada bank. Sedangkan solvabilitas bank menjadi berkurang sebagai akibat dari bertambahnya kewajiban bagi bank untuk membentuk pencadangan penghapusan aktiva produktif akibat dari terjadinya kredit macet tersebut

Beberapa penelitian menunjukkan bahwa kinerja perbankan syariah lebih baik daripada kinerja perbankan konvensional (Jahya and Iqbal, 2012). Hal ini terlihat dari beberapa rasio keuangan perbankan syariah (CAR, NPF, dan BOPO) lebih kecil daripada rasio keuangan perbankan konvensional (CAR, NPL, dan BOPO), sebaliknya rasio keuangan (ROA, ROE, dan FDR) dari bank syariah lebih besar daripada rasio keuangan (ROA, ROE, dan LDR) dari bank konvensional. Hasil penelitian ini konsisten dengan hasil penelitian Sukmana dan Febriyanti (2016) yang menemukan bahwa CAR, ROA, BOPO dan NPL bank konvensional lebih tinggi daripada bank syariah. (Solihatun, 2014) dan (Setyawati, et al., 2017) menyatakan bahwa FDR berpengaruh positif signifikan, ROA berpengaruh negatif signifikan, dan tingkat inflasi tidak berpengaruh signifikan. (Mares, 2013) menunjukkan bahwa GDP, FDR berpengaruh positif tidak signifikan terhadap pembiayaan bermasalah; inflasi dan sertifikat wadiah Bank Indonesia dan RR berpengaruh negatif tidak signifikan terhadap pembiayaan bermasalah; dan total aset berpengaruh negatif signifikan terhadap pembiayaan bermasalah. Begitu juga hasil (Maidalena, 2014) yang menyatakan bahwa CAR berpengaruh positif signifikan terhadap NPF. Chandra (2017) menyatakan bahwa NPF bank syariah tinggi bukan dikarenakan kredit macet,

Saifullah (2010), Wasiuzzaman and Gunasegavan (2013), dan Khediri et al. (2015) menunjukkan bahwa bank syariah mempunyai resiko likuiditas yang lebih kecil daripada bank konvensional. Temuan ini senada dengan hasil penelitian Rozzani dan Rahman (2013), Erol et al. (2014), dan Hadriche (2015) bahwa bank syariah lebih profit daripada bank konvensional. Sebaliknya berbeda dengan temuan Fayed (2012) dan Wasiuzzaman and Gunasegavan (2013). Khediri et al. (2015) juga menambahkan bahwa kinerja kredit bank syariah lebih baik daripada bank konvensional namun hasil ini tidak senada dengan temuan Fayed (2012). Ika dan Norhayati (2011) menyimpulkan bahwa bank syariah di Indonesia lebih liquid daripada bank konvensionalnya. Hamid and Azmi (2011) menemukan bahwa ada perbedaan yang tidak signifikan rasio profitabilitas, likuiditas, resiko dan solvabilitas antara bank syariah Malaysia dengan bank konvensional Malaysia. Usman and Khan (2012) menunjukkan bahwa tingkat profitabilitas dan pertumbuhan bank syariah Malaysia lebih tinggi daripada bank konvensional Malaysia.

\section{Hipotesis:}

Ha: terdapat perbedaan rasio pembiayaan bermasalah bank syariah dengan bank konvensional.

\section{METODE PENELITIAN}

Jenis penelitian ini adalah penelitian kuantitatif. Penelitian kuantitatif menekankan pada pengujian teori-teori melalui pengukuran variabel-variabel penelitian dengan angka dan melakukan analisis data dengan prosedur statistik (Indriantoro, Nurdan dan Supomo, 1999). Populasi penelitian ini seluruh bank syariah yang terdaftar di Bank Indonesia dan bank konvensional yang terdaftar di Bursa Efek Indonesia tahun 2012-2016 dengan teknik pengambilan sampel menggunakan purposive sampling dengan kriteria: (1) bank konvensional yang memiliki syariah; (2) bank tersebut 
menerbitkan annual report selama tahun pengamatan; dan (3) bank tersebut menyajikan data terkait pembiayaan bermasalah yang terpublikasikan di masing-masing website-nya dan menggunakan mata uang rupiah. Berdasarkan kriteria-kriteria tersebut di peroleh sampel penelitian sebanyak 10 bank syariah dan 10 bank konvensional. Jenis data penelitian ini menggunakan data sekunder yang bersumber dari masing-masing website bank yang berupa annual report tahun 2012-2016. Teknik pengumpulan data menggunakan teknik dokumentasi, dimana semua data yang terkait dengan penelitian ini di input dan diolah dengan menggunakan analisis independen sample T test, yang sebelumnya melalui uji normalitas dan uji homogenitas (Ghozali, 2013).

Variabel pembiayaan bermasalah menggunakan proksi Non Performing Financing (NPF) untuk bank syariah dan Non Performing Loans (NPL) untuk bank konvensional. Non
Performing Financing (NPF) merupakan rasio keuangan yang berkaitan dengan risiko kredit yakni perbandingan antara total pembiayaan bermasalah dengan total pembiayaan yang di berikan kepada debitur (Indriastuti and Kartika, 2018; Kasmir, 2010). Non Performing Loans (NPL) merupakan perbandingan kredit yang tidak dapat dikembalikan oleh debitur (kredit macet) dengan total kredit yang dsalurkan bank ke masyarakat (Kasmir, 2010).

\section{HASIL DAN PEMBAHASAN \\ Hasil Uji Normalitas}

Hasil pengujian normalitas dengan menggunakan SPSS menunjukkan bahwa data NPF bank syariah dan NPL bank konvensional berdistribusi normal. Hal ini terlihat dari nilai asimp. Sig untuk NPF bank syariah dan NPL bank konvensioanl diatas 5\% yakni sebesar 0.892 dan 0.147 (terlihat pada tabel 1 dibawah ini:

Tabel 1: Hasil Uji Normalitas

One-Sample Kolmogorov-Smirnov Test

\begin{tabular}{|ll|r|r|}
\hline & & Syariah & Konven \\
\hline N & & 50 & 50 \\
Normal Parameters & & 2.6470 & 1.2976 \\
& Mean & 1.79491 & .95352 \\
Most Extreme Differences & Std. Deviation & .082 & .162 \\
& Absolute & .082 & .162 \\
& Positive & -.077 & -.125 \\
& Negative & .578 & 1.143 \\
Kolmogorov-Smirnov Z & & .892 & .147 \\
Asymp. Sig. (2-tailed) & & & \\
\hline \multicolumn{2}{|c|}{ a. Test distribution is Normal. } & & \\
\multicolumn{2}{|c|}{ Sum }
\end{tabular}

Sumber: olah data SPSS, 2018

\section{Hasil Uji Homogenitas}

Hasil uji homogenitas menunjukkan nilai signifikansinya di bawah $5 \%$ sehingga dapat dinyatakan bahwa varian dari dua atau lebih kelompok populasi data tidak sama (tabel $3)$.

\section{Hasil Uji Independen Sample T test}

Hasil olah data menggunakan SPSS

(tabel 2) menunjukkan bahwa terdapat perbedaan pembiayaan bermasalah antara bank syariah dengan bank konvensional, terlihat dari nilai signifikan 2 tailed nya di bawah 5\%, artinya Ha diterima. Tabel 2 menujukkan bahwa rata-rata pembiayaan bermasalah pada bank syariah sebesar $2,64 \%$ sedangkan rata-rata pembiayaan bermasalah pada bank konvensional sebesar $1,29 \%$. Hal ini mengindikasikan bahwa pembiayaan bermasalah pada bank syariah lebih buruk dibandingkan dengan pembiayaan bermasalah pada bank konvensional. Oleh 
karena itu, bank syariah lebih berhati-hati dalam $\quad$ penyaluran pembiayaan modal kerja.

Tabel 2: Hasil Group Statistics

Group Statistics

\begin{tabular}{|ll|r|r|r|r|}
\hline \multicolumn{1}{|c|}{ Bank } & $\mathrm{N}$ & Mean & Std. Deviation & Std. Error Mean \\
\hline Rasio $\quad$ Syariah & 50 & 2.6470 & 1.79491 & .25384 \\
& & & & \\
& Konvensional & 50 & 1.2976 & .95352 & .13485 \\
\hline
\end{tabular}

Sumber: olah data SPSS, 2018

Tabel 3: Hasil Independent Sample T test

Independent Samples Test

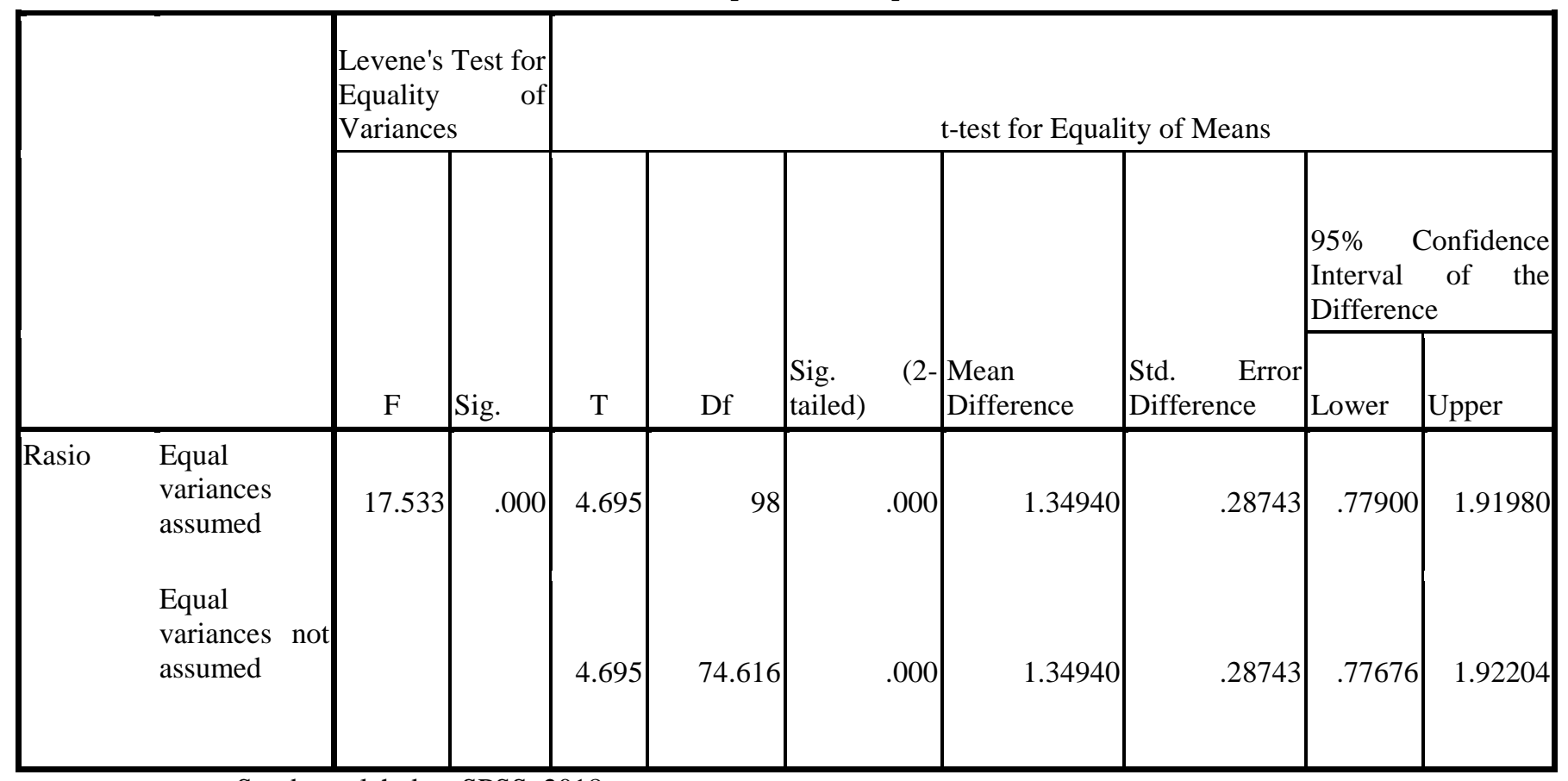

Sumber: olah data SPSS, 2018

PEMBAHASAN

Hasil pengujian independent $\mathrm{T}$ test menunjukkan bahwa terdapat perbedaan pembiayaan bermasalah antara bank syariah dengan bank konvensional. Rata-rata pembiayaan bermasalah pada bank syariah sebesar 3,2\% sedangkan rata-rata pembiayaan bermasalah pada bank konvensional sebesar $1,3 \%$. Hal ini mengindikasikan bahwa pembiayaan bermasalah pada bank syariah lebih buruk dibandingkan dengan pembiayaan bermasalah pada bank konvensional. Buruknya rasio NPF bank syariah ini membuat bank syariah harus lebih berhati-hati dalam penyaluran pembiayaan modal kerja.

Peningkatan pembiayaan bermasalah pada bank syariah dikarenakan under control costumer atau di luar kontrol nasabah, terjadi penurunan aset yang menyebabkan pembaginya akan lebih besar. Total aset turun karena bank 
tidak bisa ekspansi pembiayaan dalam kondisi ekonomi sekarang ini. Saat pembiayaan tidak tumbuh, NPF akan naik. Jika aset bank-bank syariah tidak turun mungkin NPF tidak mengalami peningkatan. Selain itu, biaya dana (cost of fund) relatif tinggi. Sebab, tidak banyak dana murah di portofolio bank syariah. Perputaran uang tidak banyak di bank syariah, lebih banyak dana mahal seperti deposito, sehingga, hal itu menjadi tantangan bagi industri perbankan syariah untuk mencari cara menyiapkan dana murah.

Selain itu, ketersediaan infrastruktur dan network (jaringan) perbankan syariah belum menjangkau sampai ke pelosok. Mulai dari sisi kompleksitas produk, mayoritas nasabah berminat pada prosedur yang tidak banyak dokumen. Nasabah yang datang karena tertarik sistem bagi hasil yang tinggi. Nasabah bagus atau grade A terbiasa dengan konsep konvensional. Sementara di bank syariah nasabah setiap bulan harus membuat laporan (report) kepada bank sebagai pertimbangan dalam konsep bagi hasil. Pangsa pasar atau market share perbankan syariah masih 4,9 persen sehingga dana yang dihimpun belum bisa disalurkan secara maksimal. (Solihatun, 2014) dan (Setyawati, et al., 2017) menyatakan bahwa tinggi rendahnya pembiayaan bermasalah di dunia perbankan di pengaruhi oleh FDR, GDP, total asset, dan ROA. sebaliknya (Mares, 2013) menunjukkan bahwa GDP, FDR tidak berpengaruh terhadap pembiayaan bermasalah. (Maidalena, 2014) menyatakan bahwa inflasi, sertifikat wadiah Bank Indonesia dan RR tidak berpengaruh terhadap pembiayaan bermasalah.

Hasil penelitian ini didukung oleh (Eris, 2013) ada perbedaan kinerja perbankan syariah dengan perbankan konvensional. Fayed (2012) dan Wasiuzzaman and Gunasegavan (2013) mengatakan bahwa bank konvensional lebih profit daripada bank syariah. Fayed (2012) juga mengatakan bahwa kinerja kredit bank syariah lebih buruk daripada bank konvensional.

Namun berbeda dengan hasil penelitian (Jahya and Iqbal, 2012) yang menunjukkan bahwa kinerja perbankan syariah lebih baik daripada kinerja perbankan konvensional. (Ika dan Norhayati, 2011) menyatakan kinerja bank syariah lebih unggul daripada bank konvensional, yakni bank syariah lebih liquid disbanding bank konvensional. Saifullah (2010), Wasiuzzaman and Gunasegavan (2013), dan
Khediri et al. (2015) menunjukkan bahwa bank syariah mempunyai resiko likuiditas yang lebih kecil daripada bank konvensional. Rozzani dan Rahman (2013), Erol et al. (2014), dan Hadriche (2015) menunjukkan bahwa bank syariah lebih profit daripada bank konvensional. Khediri et al. (2015) juga menambahkan bahwa kinerja kredit bank syariah lebih baik daripada bank konvensional. Hamid and Azmi (2011) menemukan bahwa ada perbedaan yang tidak signifikan rasio profitabilitas, likuiditas, resiko dan solvabilitas antara bank syariah dengan bank konvensional. Usman and Khan (2012) menunjukkan bahwa tingkat profitabilitas dan pertumbuhan bank syariah lebih tinggi daripada bank konvensional.

\section{KESIMPULAN}

Berdasarkan hasil penelitian dapat disimpulkan bahwa rata-rata pembiayaan bermasalah pada bank syariah (sebesar 2,64\%) lebih tinggi daripada rata-rata pembiayaan bermasalah pada bank konvensional (sebesar 1,29\%). Hasil ini mengindikasikan meskipun Indonesia adalah salah satu komunitas Muslim terbesar di dunia, kesadaran mereka tentang produk dan layanan yang sesuai dengan syariah masih rendah. Bahkan setelah dikeluarkannya fatwa MUI tentang larangan bunga, kinerja keuangan bank syariah di Indonesia masih tidak menunjukkan perbedaan statistik. Oleh karena itu, pihak bank syariah dapat melakukan sinergi kebijakan antara otoritas dengan pemerintah dan stakeholder lainnya, memperkuat permodalan dan skala usaha serta memperbaiki efisiensi, perbaikan struktur dana, kualitas layanan dan produk, kuantitas dan kualitas sumber daya manusia (SDM) dan infrastruktur lainnya, peningkatan literasi dan preferensi masyarakat dan memperkuat serta harmonisasi pengaturan dan pengawasan.

\section{DAFTAR PUSTAKA}

Akhtar, Muhammad Farhan., Ali, Khizer., Sadaqat, Shama. 2011. Liquidity Risk Management: A Comparative Study Between Conventional and Islamic Bank of Pakistan. Interdisciplinary Journal of 
Research in Business, Vol. 1, No. 1, pp. 35-44.

Bank Indonesia. 2016a. Buku Statistik Perbankan Indonesia (SPI).

Bank Indonesia. 2016b. Laporan Tahunan Bank Indonesia.

Chandra, A. A. 2017. Kiprah OJK di 2016, Dongkrak Kredit dan Tekan NPL.

Eris, Muhammad, H. 2013. Analisis Perbandingan Kredit Macet antara Perbankan Syariah dengan Perbankan Konvensional. Retrieved from http://erisheryanto.blogspot.com/2013/06/a nalisis- perbandingan-kredit-macet. html.

Erol, C., Baklaci, H.F., Aydogan, B \& Tunc, G. 2014. Performance comparison of Islamic (participation) banks and commercial banks in Turkish banking sector. EuroMed Journal of Business 9(2): 114-128

Faiz, I. A. 2010. Ketahanan kredit perbankan syariah terhadap krisis keuangan global. Jurnal Ekonomi Islam La_Riba, Vol 4, No 2 : 217-237. https://doi.org/10.20885/lariba.vol4.iss2.art 5

Fayed, M.E. 2013.Comparative performance study of conventional and Islamic Banking in Egypt. Journal of Applied Finance \& Banking 3(2): 1-14.

Firmansyah, Irman. 2014. Determinant of Non Performing Loan: The Case of Islamic Bank in Indonesia. Bulletin of Monetary, Economics and Banking, Volume 17, Number $2: 251-268$.

Ghozali, I. 2013. Analisis Multivariate dengan Program SPSS. Fakultas Ekonomi Universitas Diponegoro.

Hamid., M.A. \& Azmi., S.M. 2011. The performance of banking during 2000-2009: Bank Islam Malaysia Berhad and conventional banking in Malaysia. International Journal of Economics and Management Sciences 1(1): 9-19.

Hadriche, M. 2015. Bank performance determinants: Comparative analysis between conventional and Islamic Banks from GCC countries. International Journal of Economics and Finance 7(9): 169-177.

Ika, S.R dan Norhayati, A. 2011. A Comparative Study of Financial Performance of Islamic Banks and Conventional Banks in
Indonesia. International Journal of Business and Social Science, Vol 2, No 15 : 199-207.

Indriantoro, Nurdan dan Supomo, B. 1999. Metodologi Penelitian Bisnis Untuk Akuntansi \& Manajemen. Yogyakarta: Penerbit BPFE.

Indriastuti, Maya dan Kartika, Indri. 2018. The Minimalization of Non Performing Financing in Improving The Performance Sharia Bank. Semarang: Unissula Press.

Iqbal, Anjum. 2012. Liquidity Risk Management: A Comparative Study Between Conventional and Islamic Bank of Pakistan. Global Journal of Management and Business Research, Vol.

12, No. 5, 54-64

Jahya, Susilo Adi and Iqbal, M. 2012. Analisis Perbandingan Kinerja Keuangan Perbankan Syariah dengan Perbankan Konvensional. Episteme., Volume. 7.

Kasmir. 2010. Pengantar Manajamen Keuangan. In Cetakan II, Edisi I. Jakarta: Kencana.

Khediri, K.B., Charfeddine, L., Youssef, S.B. 2015. Islamic versus conventional banks in the GCC countries: A comparative study using classification techniques. Research in International Business and Finance 33: 75-98.

Maidalena. 2014. Analisis Faktor Non Performing Financing (NPF) pada Industri Perbankan Syariah. Human Falah., Vol 1, No 1.

Mares, P. S. A. 2013. Analisis Penyebab Terjadinya Non Performing Financing Pada Bank Umum Syariah di Indonesia. Accounting Analysis Journal, 2 (4). ISSN 2252-6765.

Misra, B.M. dan Sarat Dhal. 2010. "Pro-cyclical management of non-performing loans by the Indian public sector banks". BIS Asian Research Papers, Juni.

Muhammad Djibril. 2015. Bank Syariah Gede Bukan karena Kredit Macet. Retrieved from www.republika.co.id

Otoritas Jasa Keuangan (OJK). 2016. Laporan Perkembangan Keuangan Konvensional. Retrieved from www.ojk.go.id

Rozzani, N. \& Rahman, R.A. 2013. Determinants of Bank performance: Conventional versus Islamic. Jurnal Pengurusan 39: 129-139

Saifullah, M. 2010. Superiority of conventional 
banks and Islamic Bank of Bangladesh: A comparative Study. International Journal of Economics and Finance 2(3): 199-207.

Setyawati Irma, Suroso Sugeng, Suryanto Tulus, dan N. S. D. 2017. Does Financial Performance of Islamic Banking is better? Panel Data Estimation. European Research Studies Journal, Issue XX.

Solihatun. 2014. Analisis Non Performing Financing (NPF) Bank Umum Syariah di Indonesia tahun 2007-2012. Jurnal Ekonomi Pembangunan, Vo 12, No 1.

Sukmana, Raditya dan Febriyati, Nur Ahlina. 2016. Islamic Banks vs Conventional Banks in Indonesia: An Analysis on Financial Performances. Jurnal Pengurusan. Vol 47 $\begin{array}{llll}: & 81 & - & 90 .\end{array}$ http://dx.doi.org/10.17576/pengurusan2016-47-07.

Wasiuzzaman, S. \& Gunasegavan, U.N. 2013. Comparative study of the performance of Islamic and conventional banks: The case of Malaysia. Humanomics 29(1): 43-60. 